\title{
CONSIDERATIONS ABOUT Coscinodiscus wailesii (DIATOMEAE) ON THE SANTA CATARINA ISLAND COAST, BRAZIL
}

\author{
Dávia Talgatti $^{{ }^{*}}$, Roselane Laudares-Silva ${ }^{1}$, Marinês Garcia ${ }^{2}$, Bianca Vettorato ${ }^{l}$ and José Carlos Simonassi $^{3}$ \\ ${ }^{1}$ Universidade Federal de Santa Catarina - Departamento de Botânica, Laboratório de Ficologia \\ Programa de Pós-graduação em Biologia Vegetal \\ (Caixa Postal 476, 88049-900 Florianópolis, SC, Brasil) \\ ${ }^{2}$ Universidade Federal de Pelotas, Departamento de Botânica \\ (96010-900 Pelotas, RS, Brasil) \\ ${ }^{3}$ Universidade Federal Fluminense - Instituto de Biologia \\ Programa de Pós-graduação em Biologia Marinha \\ (Caixa Postal 100.644 Niterói, RJ, Brasil) \\ *Corresponding author: daviamt@gmail.com
}

Coscinodiscus wailesii Gran et Angst, first described in the Pacific Ocean by Hasle and Lange (1992) but which has since been occupying oceans and coastal seas all over the world, is considered an invasive species. It is frequently found in high concentrations as the dominant organism with densities higher than 90\% (DÜRSELEN; RICK, 1999; EDWARDS et al., 2001). In Brazil it has only been registered in recent studies such as those undertaken by Valente-Moreira (1987), Moreira-Filho et al. (1990), Souza-Mosimann et al. (1993), Fernandes et al. (2001) and Tenenbaum et al. (2004). It is likely that the species was introduced by the discharge of ballast water (FERNANDES et al., 2001).

The register of $C$. wailesii in Brazilian waters only as recently as 1987 may also be due to a misidentification as it is very similar to $C$. concinnus Wm. Smith. As Wiltshire and Dürselen (2004) emphasize, both species co-exist in the North Sea and have similar dimensions. It suggests that this confusion might have arisen in studies conducted in Brazil. There exists, therefore, the possibility that the occurrence of $C$. wailesii in Brazilian waters anteceded any existing publication on it.

As an invasive organism $C$. wailesii replaces the native phytoplankton by competition, decreasing biodiversity (EDWARDS et al., 2001). The success of the species is related to its resistance to different temperatures and salinities, higher tolerance to heavy metals than is shown by native species and the large size of its cells, unpalatable to planktonic herbivores (DÜRSELEN; RICK, 1999).

Coscinodiscus wailesii is considered a potentially harmful species due to its production of insoluble mucilage which adversely affects fishing activities (EDWARDS et al., 2001). These organisms develop high biomass leading to oxygen and nutrient depletion, adversely affecting mussel and seaweed cultivation (FERNANDES et al., 2001; PROENÇA; FERNANDES, 2004). The depletion of inorganic nitrogen in areas cultivated with the seaweed Porphyra (Nori) causes talus whitening and consequent economic loss (NISHIKAWA; YAMAGUCHI, 2008). It is important to consider the potential economic impact of $C$. wailesii in estuaries and coastal areas, especially in the Santa Catarina State where large mariculture projects are undertaken.

This study presents the cell characterization and aspects of the distribution of $C$. wailesii in the Santa Catarina Island coastal waters.

The samples analyzed were collected at three sites on Santa Catarina Island, South-Western Atlantic, Brazil (Fig. 1): the Ratones Grande Station (RGS) (27\%28'30.52”S - 48 $\left.333^{\prime} 27.27^{\prime \prime} \mathrm{W}\right)$ and Guarazes Station (GS) (27\%33'20.09'S $48^{\circ} 33^{\prime} 27.50^{\prime \prime} \mathrm{W}$ ) on the central-west coast and Pantano do Sul Station (PSS) (27\%47'24.97's $\left.48^{\circ} 30^{\prime} 39.31^{\prime \prime} \mathrm{W}\right)$ in the south-east. The RGS and GS stations receive the influence of the rivers and mangrove swamps of Ratones and Itacorubi mainly as regards their nutrient contribution, which includes phosphorus and nitrogen, and of the fresh water draining from the adjacent continental areas (PAGLIOSA et al., 2005; PAGLIOSA et al., 2006). The PSS station is located in an area open to the sea.

Sampling was carried out monthly from January 2007 to January 2008. Water was collected from the surface. Temperature and salinity were measured in situ, with an Arba thermometer and a Shibuya refractometer.

Coscinodiscus wailesii cells were quantified using an inverted microscope and following Utermöhl (1958). A complete $5 \mathrm{ml}$ chamber was counted for each sample. Ten to thirty transects in a $1 \mathrm{ml}$ chamber were counted for total phytoplankton. 


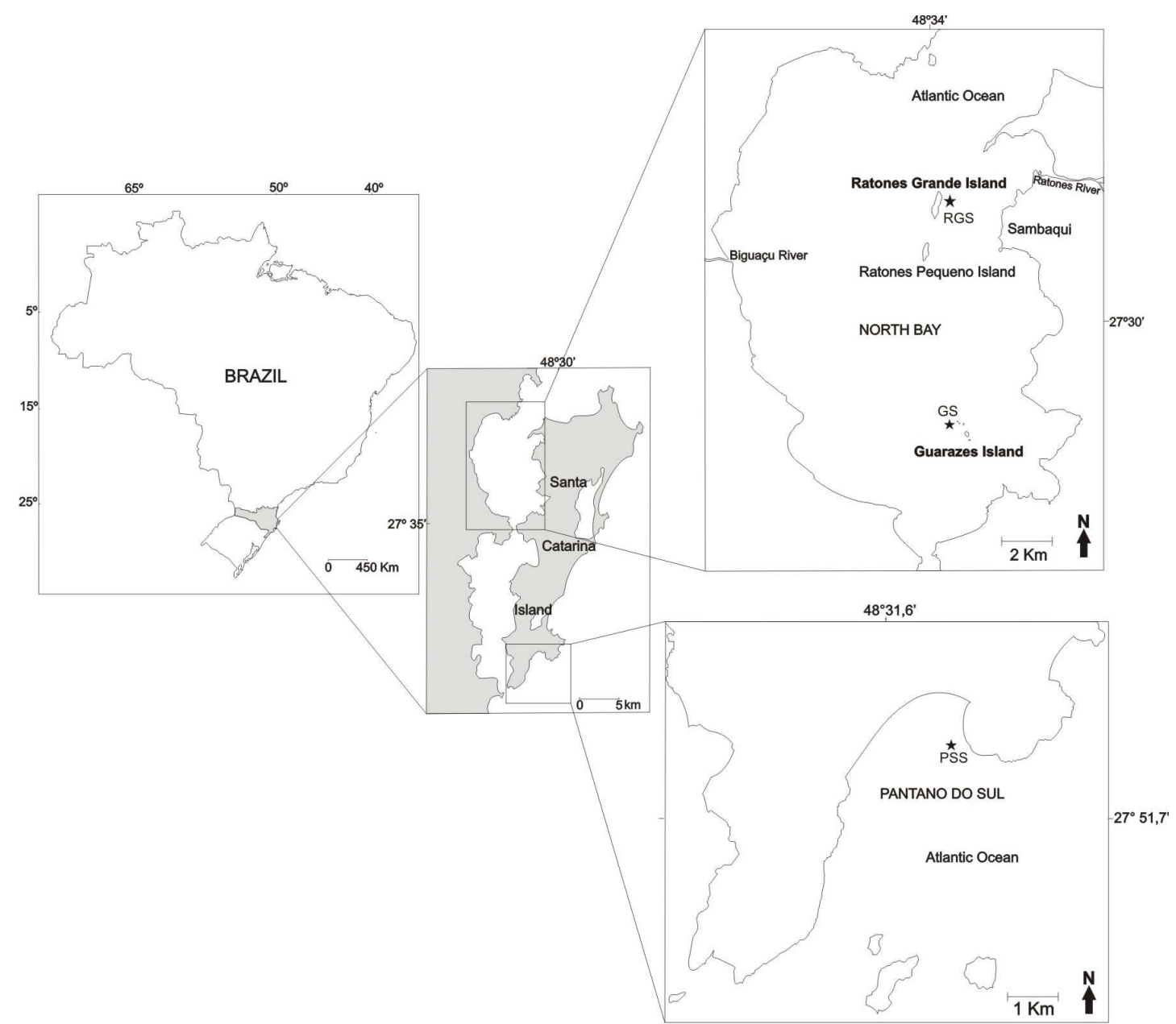

Fig. 1. Sampling sites location on the coast of Santa Catarina Island, South-Western Atlantic, Brazil. RGS: Ratones Grande Station; GS: Guarazes Station and PSS: Pantano do Sul Station.

The samples were prepared according to Simonsen_(1974) and observed under a Scanning Electron Microscope (SEM) JEOL 6390 LV. Frustule measurements and photomicrography were taken with an Optical Microscope (OM) Olympus BX 50.

Coscinodiscus wailesii present radial striation and a central hialine area with irregular borders (Fig. 2a, 2d). The areolae size increases from the center to the margins, decreasing at the joint of the valve face with the mantle. They present a deep valve mantle and a right-angle between the mantle and the marginal area of the valve face (Fig. 2b). The cell diameter varied from $208 \mu \mathrm{m}$ (PSS in January/08) to $362.5 \mu \mathrm{m}$ (RGS in April/07). The average diameter was larger in autumn $(301.5 \mu \mathrm{m})$ than in the summer $(245.4 \mu \mathrm{m})$. The number of areolae varied from 4 to $6 /$ $10 \mu \mathrm{m}(\mathrm{n}=71)$. Two rimoportulae rings are located in the joint zone between the mantle and the valve face and in the mantle's median region. The latter presents two macrorimoportulae (Fig. 2e) and there are also small rimoportulae scattered over the valve face (Figs. $2 \mathrm{c}, 2 \mathrm{f}$ ). They were located at the end of some striae that rise in the central area (Fig. 2d). The central area was in accordance with the description given by Fernandes et al. (2001). The chloroplasts are discoid, numerous and irregularly distributed within the cell. There were also resting cells in the samples. According to Nagai et al. (1996) these are characterized by cytoplasm detached from the frustule and gathered in the central area of the cells. The occurrence of two distinct types of frustule diameters in the samples may indicate the presence of resting cells, which according to Nagai et al. (1996), produce smaller diameters than the vegetative cells. 

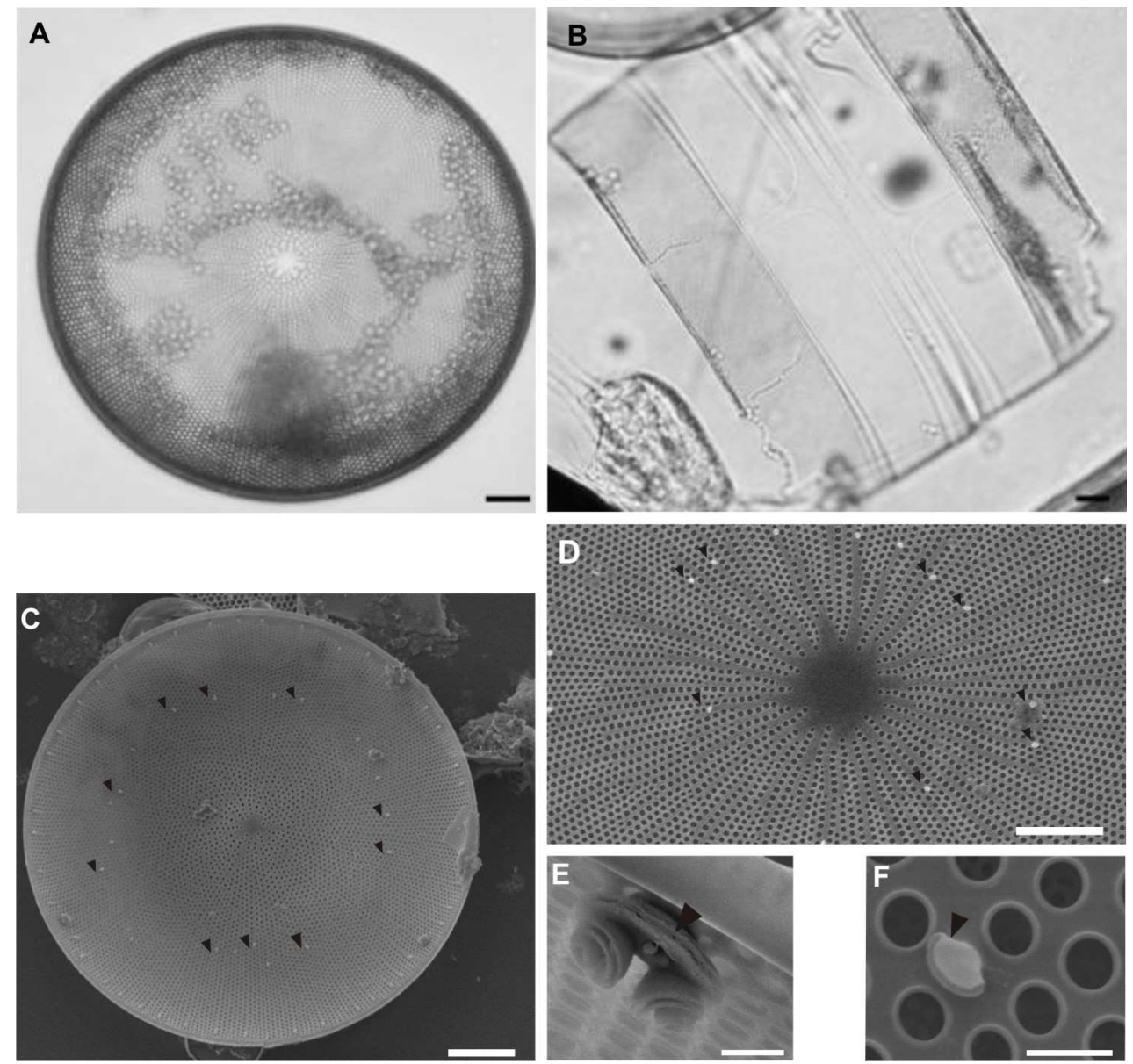

Fig. 2. Light microscopy images (Figs. A and B) and Scanning electron microscopy (Figs.C- F) of Coscinodiscus wailesii. Fig. (A): valve view; Fig. (B): girdle view; Fig. (C): general valve view showing microrimoportulae scattered on the valve face (arrows). (D): central region with interstriae of varied sizes and microrimoportulae (arrows). (E): macrorimoportula, internal view (arrow).(F): valve face microrimoportula, internal view (arrow).

The frustule morphology of Coscinodiscus wailessii accords with other descriptions of it (SCHMID; VOLCANI, 1983; HASLE; LANGE, 1992; FERNANDES et al., 2001). However, the diameter was closer to the limits registered by Fernandes et al. (2001) [195-385 $\mu \mathrm{m}]$ and did not attain the $500 \mu \mathrm{m}$ diameter cited by Schmid and Volcani (1983).

Figure 3 shows the distribution of Coscinodiscus wailesii cell density as related to total phytoplankton cell density, water temperature and salinity, during the sampling periods. The total phytoplankton cell density varied from $3,599.10^{6}$ to $4,15.10^{5}$ cells. L $^{-1}$ at PSS (Fig. 3c, 3d) and from $1,8891 \cdot 10^{7}$ to $2,193 \cdot 10^{6}$ cells. $L^{-1}$ at RGS (Fig. 3a, 3b). For Coscinodiscus wailesii, the highest growth periods were observed in April/2007 with $2,316.10^{3}$ cels. $L^{-1}$ at RGS (Fig. 3a, 3b) and in January/2008 with $1,158.10^{3}$ cels. $L^{-1}$ at PSS (Fig. 3a, 3b). It will be seen that no growth of Coscinodiscus wailesii occurred during the early winter and during spring. No $C$. wailesii cells were found at GS in the quantitative analysis. Table 1 gives the abiotic water data at the three stations sampled.

These values are similar to those of the $C$. wailesii blooms reported for Paranaguá Bay and surrounding areas (FERNANDES et al., 2001) and for the German coast (DÜRSELEN; RICK, 1999). On the Japanese coast, Nagai et al. (1996) registered blooms of $10^{2}$ cells. $\mathrm{L}^{-1}$.

The present results indicate that $C$. wailesii in Santa Catarina Island coastal waters has dynamics distinct from those present in Parana State (FERNANDES et al., 2001). There $C$. wailesii was found in every month of the year and produced blooms sporadically in Paranaguá Bay (PR). 
A

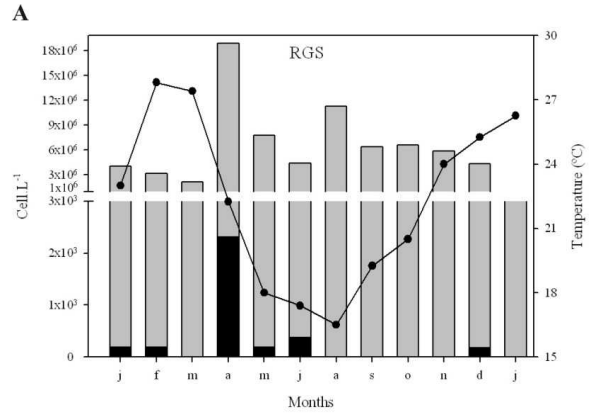

C

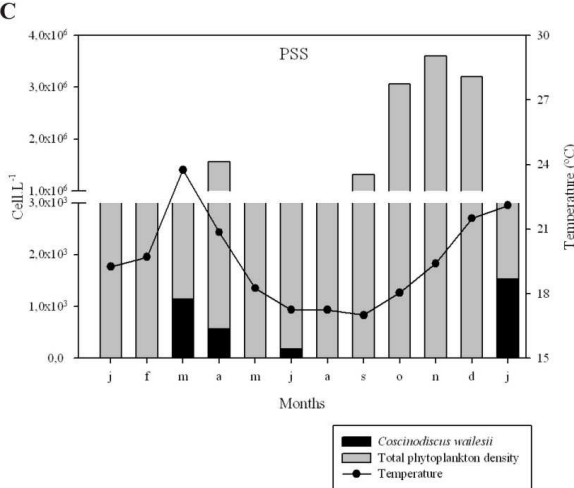

B

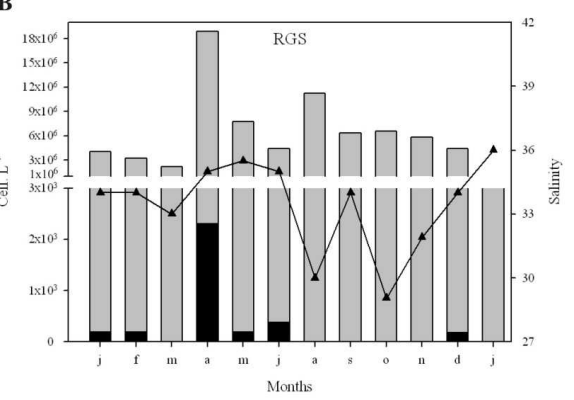

D

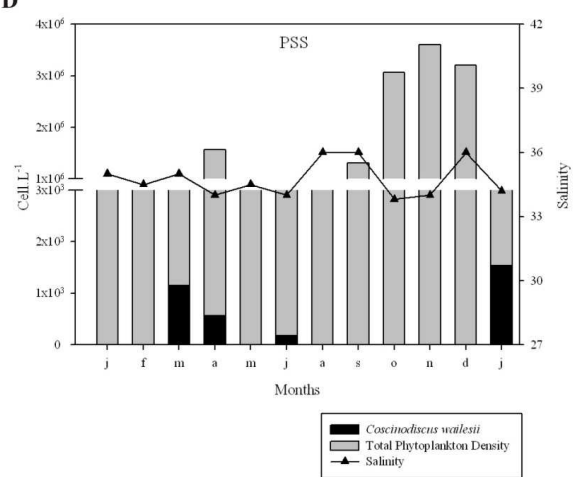

Fig. 3. Coscinodiscus wailesii density $\left(\right.$ Cells.L $L^{-1}$ ) and abiotic factors at RGS and PSS, from january/2007 to january/2008.

Table 1. Temperature (T) and Salinity (S) of the, SouthWesternAtlantic, Brazil Ratones Grande Station; GS: Guarazes Station; PSS: Pantano do Sul Station.

\begin{tabular}{|c|c|c|c|}
\hline & RGS & GS & PSS \\
\hline \multicolumn{4}{|l|}{2007} \\
\hline \multirow[t]{2}{*}{ January } & $\mathrm{T}: 23^{\circ} \mathrm{C}$ & $\mathrm{T}: 23^{\circ} \mathrm{C}$ & $\mathrm{T}: 19,25^{\circ} \mathrm{C}$ \\
\hline & S: 34 & S: 34 & S: 35 \\
\hline \multirow[t]{2}{*}{ February } & $\mathrm{T}: 27,8^{\circ} \mathrm{C}$ & $\mathrm{T}: 28,2^{\circ} \mathrm{C}$ & $\mathrm{T}: 19,7^{\circ} \mathrm{C}$ \\
\hline & S: 34 & S: 34 & S: 34,5 \\
\hline \multirow[t]{2}{*}{ March } & $\mathrm{T}: 27,3^{\circ} \mathrm{C}$ & $\mathrm{T}: 27,8^{\circ} \mathrm{C}$ & $\mathrm{T}: 23,75^{\circ} \mathrm{C}$ \\
\hline & S: 33 & S: 33 & S: 35 \\
\hline \multirow[t]{2}{*}{ April } & $\mathrm{T}: 22,25^{\circ} \mathrm{C}$ & $\mathrm{T}: 22^{\circ} \mathrm{C}$ & $\mathrm{T}: 20,85^{\circ} \mathrm{C}$ \\
\hline & S: 35 & S: 35,5 & S: 34 \\
\hline \multirow[t]{2}{*}{ May } & $\mathrm{T}: 18^{\circ} \mathrm{C}$ & $\mathrm{T}: 17,8^{\circ} \mathrm{C}$ & $\mathrm{T}: 18,25^{\circ} \mathrm{C}$ \\
\hline & S: 35,5 & S: 35 & S: 34,5 \\
\hline \multirow[t]{2}{*}{ July } & $\mathrm{T}: 17,4^{\circ} \mathrm{C}$ & $\mathrm{T}: 17,5^{\circ} \mathrm{C}$ & $\mathrm{T}: 17,25^{\circ} \mathrm{C}$ \\
\hline & S: 35,5 & S: 35 & S: 34 \\
\hline \multirow[t]{2}{*}{ August } & $\mathrm{T}: 16,5^{\circ} \mathrm{C}$ & $\mathrm{T}: 16,5^{\circ} \mathrm{C}$ & $\mathrm{T}: 17,25^{\circ} \mathrm{C}$ \\
\hline & S: 30 & S: 30 & S: 36 \\
\hline \multirow[t]{2}{*}{ September } & $\mathrm{T}: 19,25^{\circ} \mathrm{C}$ & $\mathrm{T}: 19^{\circ} \mathrm{C}$ & $\mathrm{T}: 17^{\circ} \mathrm{C}$ \\
\hline & S: 34 & S: 35 & S: 36 \\
\hline \multirow[t]{2}{*}{ October } & $\mathrm{T}: 20,5^{\circ} \mathrm{C}$ & $\mathrm{T}: 21^{\circ} \mathrm{C}$ & $\mathrm{T}: 18,05^{\circ} \mathrm{C}$ \\
\hline & S: 29,05 & S: 30,1 & S: 33,8 \\
\hline \multirow[t]{2}{*}{ November } & $\mathrm{T}: 24^{\circ} \mathrm{C}$ & $\mathrm{T}: 24,5^{\circ} \mathrm{C}$ & $\mathrm{T}: 19,4^{\circ} \mathrm{C}$ \\
\hline & S: $31,9^{\circ} \mathrm{C}$ & S: 32,1 & S: 34 \\
\hline \multirow[t]{2}{*}{ December } & $\mathrm{T}: 25,25$ & $\mathrm{~T}: 25,5^{\circ} \mathrm{C}$ & $\mathrm{T}: 21,5^{\circ} \mathrm{C}$ \\
\hline & S: 34 & S: 34 & S: 36 \\
\hline \multicolumn{4}{|l|}{2008} \\
\hline \multirow[t]{2}{*}{ January } & $\mathrm{T}: 26,25^{\circ} \mathrm{C}$ & $\mathrm{T}: 28^{\circ} \mathrm{C}$ & $\mathrm{T}: 22,1^{\circ} \mathrm{C}$ \\
\hline & S: 33 & S: 33 & S: 34,2 \\
\hline
\end{tabular}

Table 2 shows Coscinodiscus wailesii density percentages as related to total phytoplankton density. The results indicate but a small contribution of $C$. wailesii to total phytoplankton. The relative density of $C$. wailesii was greater at PSS than at RGS. Nevertheless the discrepancy between $C$. wailesii cell volume and the majority of the phytoplankters identified in the samples makes comparisons based on cell number unreal.

However, the discrepancy between $C$. wailesii cell volume and that of the majority of the phytoplankters identified in the samples makes comparisons based on cell number of doubtful value.

The water temperature at the stations studied presented a variation of $11.3^{\circ} \mathrm{C}$ between the coldest and the warmest months at RGS and of $6.75^{\circ} \mathrm{C}$ at PSS. The salinity presented a greater variation at RGS (6.9) than at PSS. However, there were no significant positive correlations between $C$. wailesii cell density and temperature or between cells density and salinity. The species occur over a broad temperature range, from $1{ }^{\circ} \mathrm{C}$ to $30.9^{\circ} \mathrm{C}$ (NAGAI et al., 1996, DÜRSELEN; RICK, 1999; FERNANDES et al., 2001). We do not believe that the variation in salinity observed had any direct effect on population growth since the species is highly tolerant of salinity variations, from 8 to 35 psu (FERNANDES et al., 2001). 
Table 2. Phytoplankton total density and Coscinodiscus wailesii relative density at RGS and PSS in the Santa Catarina Island, South-Western Atlantic, Brazil.

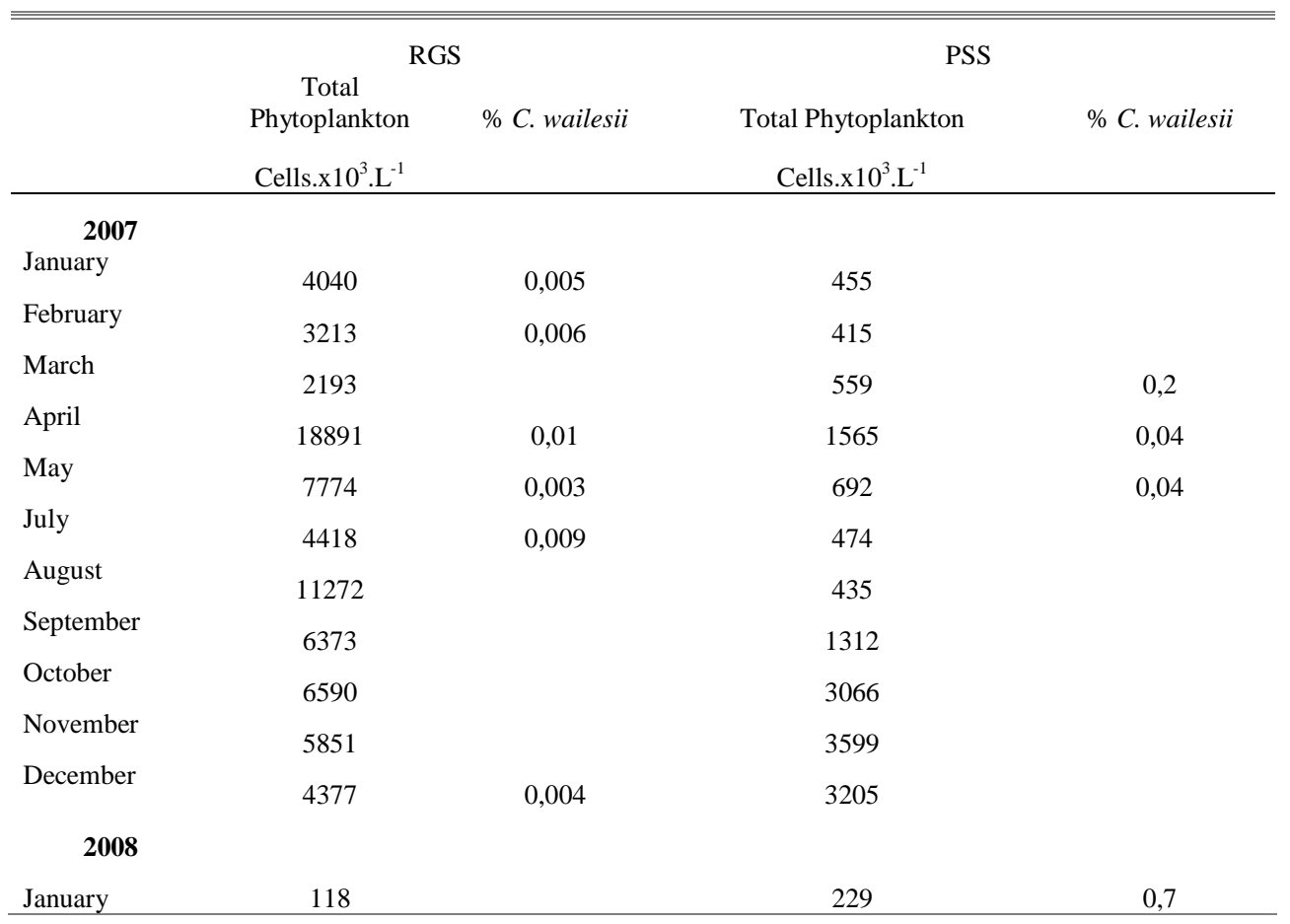

Nagai et al. (1996) concluded that $C$. wailesii vegetative cells become resting cells that remain on the sediment when the water column is stratified. During turnover periods these cells may then re-enter the water column and, if the environmental conditions are favourable, grow to ensure the continuity of the life cycle (NAGAI et al., 1996; NISHIKAWA; YAMAGUCHI, 2008). Nagai et al. (1996) observed that the recurrence of autumn blooms depended on the number of resting cells in the sediment. In the Santa Catarina Island coastal waters, future studies on population dynamics of $C$. wailesii should be followed by investigations of the thermal and saline characteristics of the water column, nutrient analyses and quantification of vegetative and resting cells in the sediment. The quantification of the resting cells in the sediment is essential for monitoring programs, seeing that these data together with the abiotic data may be used to foresee the occurrence of blooms and thus make it possible for preventive actions against its noxious effects to be taken.

\section{REFERENCES}

DÜRSELEN, C. D.; RICK, H. J. Spatial and temporal distribution of two new phytoplankton diatom species in the German Bight in the period 1988 and 1996. Sarsia, v. 84, p. $367-377,1999$.
EDWARDS, M.; JOHN, A. W. G.; JOHNS, D. G.; REID, P. C. Case history and persistence of the non-indigenous diatom Coscinodiscus wailesii in the north-east Atlantic. J. mar. biol. Ass. U. K., v. 81, p. 207-211, 2001.

FERNANDES, L.; ZEHNDER-ALVES, L.; BASSFELD, J. The recently established diatom Coscinodiscus wailesii (Coscinodiscales, Bacillariophyta) in Brazilian waters. I: Remarks on morphology and distribution. Phycol. Res., v. 49, p. 89-96, 2001.

HASLE, G. R.; LANGE, C. Morphology and distribution of Coscinodiscus species from the Oslofjord, Norway, and the Skagerrak, North Atlantic. Diatom Res., v. 7, n. 1, p. 37-68, 1992.

MOREIRA-FILHO, H.; VALENTE-MOREIRA, I. M.; SOUZA-MOSIMANN, R. M.; CUNHA, J. A. Floristic and ecological evaluation of marine and estuarine diatoms (Chrysophyta, Bacillariophyceae) of Paraná and Santa Catarina. Estud. Biol., Pontifícia Univ. Católica do Paraná, v. 25, p. 5-48, 1990.

NAGAI, S.; HORI, Y.; MIYAHARA, K.; MANABE, T.; IMAI, I. Population dynamics of Coscinodiscus wailesii Gran et Angst (Bacillariophyceae) in Harina-Nada, Seto Island Sea, Japan. In: YASUMOTO, T.; OSHIMA, Y.; FUKUYO, Y. (Ed.). Harmful and toxic algal blooms. Japan: Intergovernmental Oceanographic Commission of UNESCO, 1996. p. 239-242.

NISHIKAWA, T; YAMAGUCHI, M. Effect of temperature on light-limited growth of the harmful diatom Coscinodiscus wailesii, a causative organism in the bleaching of aquacultured Porphyra thalli. Harmful Algae, v. 7, p. 561-566, 2008. 
PAGLIOSA, P. R.; FONSECA, A.; BOSQUILHA, G. E.; BRAGA, E. S.; BARBOSA, F. A. Phosphorus dynamics in water and sediments in urbanized and non-urbanized rivers in Southern Brazil. Mar. Pollut. Bull., v. 50, p. 965-974, 2005.

PAGLIOSA, P. R.; FONSECA, A.; BARBOSA, F. A BRAGA, E. S. Urbanization impact on subtropical estuaries: a comparative study of water properties in urban areas and in protected areas. J. coast Res., special issue, v. 39, p. 731-735, 2006.

PROENÇA, L. A.; FERNANDES, L. F. Introdução de microalgas no ambiente marinho: impactos negativos e fatores controladores. In: SILVA, J. S. V.; SOUZA, R. C. C. L. (Ed.). Água de lastro e bioinvasão. Porto Alegre: Interciência, 2004. p. 77-97.

SCHMID, A. M. VOLCANI, B. E. Wall morphogenesis in Coscinodiscus wailesii Gran and Angst. J. Phycol., v. 19, p. 387-402, 1983.

SIMONSEN, R. The diatom plankton of the Indian Ocean Expedition of R/V 'Meteor'. Meteor Forschergebn., v. 19 (d), p. 1-107, 1974

SOUZA-MOSIMANN, R. M.; FELÍCIO-FERNANDES, G.; SILVA, R. L.; FERNANDES, L. F. Diatoms from stomach contents of three shrimp species of artesanal marine fishery in Santa Catarina State, Brazil. Insula, v. 22, p. 83-106, 1993.
TENENBAUM, D. R.; VILLAC, M, C.; MATOS, M.; HATHERLY, M.; LIMA, I.V.; MENEZES, M. Phytoplankton Atlas of Sepetiba Bay, Rio de Janeiro, Brazil. IMO London: Globallast Monograph series, n. $16,2004.132 \mathrm{p}$.

UTERMÖHL, H. Zur Vervollkommung der quantitativen phytoplankton-methodik. Mitt. int. Verein. theor. angew. Limnol., v. 9, p. 1-38, 1958.

VALENTE-MOREIRA, I. M. The marine and estuarine diatom flora in the balnearies of Canoas and Ipanema, Paraná State, Brazil. Estud. Biol., Pontifícia Univ. Católica do Paraná, v. 17, p. 26-48, 1987.

WILTSHIRE, K. H.; DÜRSELEN, C. D. Revision and quality analyses of the Helgoland Reede long-term phytoplankton data archive. Helgol. mar. Res., v. 58, p. 252-268, 2004.

(Manuscript received 20 March 2010; revised 05 May 2010; accepted 13 July 2010) 